\title{
SYSTEEMI- JA ORGANISAATIOTASON
}

\section{OPPIMISTUTKIMUS}

EVELIINA SAARI (2003)

The Pulse of Change in Research Work. A Study of Learn-ing and Development in a Research Group.

Helsinki University Press.

Eveliina Saaren väitöskirja on tervetullut panos suomalaiseen tieteen- ja teknologian tutkimukseen. Kenttätyöhön perustuvat kuvaukset tutkimustoiminnan ruohonjuuritasolta antavat usein keskustelulle kiinnekohtia pitkäksi aikaa. Eveliina Saaren työ antaa käsitteistystä tutkijoiden, yritysten ja loppukäyttäjien verkoston tapahtu- mille. Tutkimus lukeutuu systeemi- ja organisaatiotason oppimisen tutkimukseen, mutta yhtä lailla sitä voi pitää nykyaikaisena laboratorioetnografiana. Yksi työn erityispiirre on harvinaisen hyvä aikaulottuvuus, joka riittää paljastamaan tutkimustoiminnan pitkäjänteis- 
täkin dynamiikkaa.

Tekijän erityinen pyrkimys on yrittää tähänastista syvemmällä tavalla ymmärtää tutkimusryhmien suhdetta käytäntöön, sovellutuksiin ja käyttäjiin. Tutkielma kuvaa ja käsitteistää sovellutuksia lähellä olevan tutkimustyön ja luonteeltaan perustutkimuksellisemman työn jännitteistä suhdetta.

\section{TEKNOLOGISEN RYHMÄN KEHITYSKAARI}

Väitöskirja käyttää tapauksina VTT:n aerosoliteknologian ryhmän ja sen USA:laisen vastineen kehityskaaria 1990-luvun alusta lähes nykypäivään asti. Aerosoliteknologian sovellukset ja potentiaaliset sovellukset sijoittuvat varsin erilaisten käytäntöjen piiriin kuten syövänhoito, ydinvoimalaonnettomuudet, polttotekniikka ja kaasujen puhdistaminen sekä erittäin puhtaiden materiaalien tuottaminen.

Tapaustutkimuksilla on yleispätevyyttä, vaikka tapahtumien kulku epäilemättä ei koskaan sellaisenaan toistu. Yhden teknologisen huippualan dynamiikkaa koskeva kuvaus paljastaa mekanismeja, jotka toimivat paljon laajemmalla alalla. Eveliina Saaren tulokset ovat siirrettävissä kaikkiin sovellussuuntautuneisiin tutkimusryhmiin. Mekanismeista ja riippuvuuksista erityistä huomiota kiinnittää se, miten VTT:n tutkijat joutuvat taiteilemaan eri aikajänteiden luomassa kentässä. Sovellusten kautta voi saada rahoitusta, mutta tutkimustoiminta itsessään vaatisi pitemmän aikajänteen mukaista taloudellista pohjaa. Lukija jää lopulta pohtimaan, oliko aerosoliteknologian tutkimusryhmän herooinen suoritus jännitteisessä ken- tässä todiste sovellusten ja käyttäjien hedelmällisestä roolista tutkimukselle ja näin ollen todiste tulosjohdetun tutkimusrahoituksen voimasta, vai oliko pikemminkin niin, että liian lyhyt aikajänne vaikeutti tutkimusta ja teki toisinaan tutkimusryhmän elämästä kohtuuttoman kovaa.

\section{TUTKIMUSRYHMÄN SISÄISEN DYNAMIIKAN VALOTUS}

Eveliina Saaren erityinen tavoite oli juuri tutkimusryhmän sisäisen dynamiikan ja käyttäjien roolin ymmärtäminen. Esiymmärrys ohjasi tekijää etsimään toiminnan kuluessa muotoutuvaa subjektia. Sovelluksen (sisäistä) suhdetta perustutkimukseen tekijä käsittelee tutkimuskohteiden, instrumenttien sekä käyttäjätahojen kannalta. Tekijä kuvaa, miten tutkimusryhmä ensimmäisen puoliväliin jäävän sovellus- ja käyttäjäkytkennän jälkeen operoi perustutkimuksellisemman tason kautta muihin sovellutuksiin ja rahoittajiin nähden. Välitys jäsentyy nanopartikkelien tapauksessa seuraavilla käsitteillä: nanopartikkelien spesifikaatiot, valinta, optimointi, vaikeudet ja ratkaisemattomat ongelmat, mahdollisuus ja toimivuus, lupaavat sovellusmahdollisuudet, elementtien ja perustojen vaihtomahdollisuus insinöörityössä, insinööritehtävän kääntäminen tieteellisiksi kysymyksiksi ja ajatus artikulaatiosta.

Perustutkimus operoi yleensä useiden sovellutusten yhdyssiteen alueella, ikäänkuin niiden alustassa. Titaanidioksidin tapauksessa näkyy selkeästi perustutkimuksen ja useiden potentiaalisten sovellusten si- säinen suhde. Toivotun sovelluksen kariutuminen ohjasi tutkimusryhmän takaisin 'alustaan' tai perustutkimukseen, josta käsin useat sovellukset ovat mahdollisia mutta mitään yhtä nimenomaista varten ei ole vielä tehty rajauksia tai spesifikaatioita. Tällainen sovellusten synnyn sekä tutkimuksen yhteiskunnallisen ehdollisuuden tarkastelu on aivan eri tasolla kuin innovaatioketjujen edustamat karkeat mallit.

Tekijä on joutunut tekemään melkoisen työn päästäkseen kentälle ja sisään siihen, mitä tutkimusryhmät verkostoineen kulloinkin tekevät. Tietenkin ongelmanratkaisuun ovat kykeneviä vain itse alan tutkijat, tässä siis aerosoliteknologian tutkijat ja jopa heistäkin kulloinkin vain kyseisiin tehtäviin erikoistuneet henkilöt. Mutta Eveliina Saari vakuuttaa lukijansa siitä, että aerosoloitutkijoiden tutkimuksellista pyrintöä ja problematiikan muotoutumista voidaan ulkoapäin havainnoida ja kuvata tieteen ja teknologian tutkimuksen keinoin. Voidaan siis yrittää ymmärtää, mikä tietyn suuruusluokan partikkelien problematiikka tutkijoilla on työn alla, mihin he pyrkivät ja miten he kulloinkin ovat organisoitumassa tehtäviään varten. Jopa dialogi aerosolitutkijoiden ja etnografin välillä näytti olevan mahdollista. Tutkimusryhmät omaksuivat toisinaan omaa työtään koskevaksi reflektioksi Eveliina Saaren havainnoijanäkökulmia. Esimerkkejä tästä ovat avoimen yhteistyön kariutumisen tulkinta sekä tutkimusryhmän sisäistä kasvudynamiikkaa ja tutorointia koskeva pohdinta. Asennonvaihto toimi siis molempiin suuntiin. 
YHTEISTYÖ JA

ERKANEVAT INTRESSIT

Tutkimustoiminnan perusvire uuden mahdollistamiseksi on yhteistyö. Yhteistyön erityinen kannuste oli aluksi toisiaan täydentävät taidot ja resurssit. Instrumenttien, mittaustarkkuuden ja hiljaisen tiedon rooli tulee hyvin esille.

Sovellusten syntyessä erityisesti liiketoiminnan intressit astuvat kuvaan. Tekijä tuo erinomaisesti esiin kilpailullisen suhteen synnyn tutkimusryhmien välille sovellusten, patenttien, yrityssalaisuuden ja erkanevien intressien kautta. Tietoa on myös salattava. Henkilöinä toisiinsa empaattisesti suhtautuvat ihmiset ajautuvat toimintasysteemien eriytyessä ja sulkeutuessa aivan henkilöinäkin toisistaan erilleen. Eveliina Saari vie lukijansa dramaattisesti kokemaan molempien osapuolten tappion tutkimusryhmien avainhenkilöiden joutuessa alistuneina jäädyttämään ystävälliset henkilösuhteensa. Samalla piirtyy mielenkiintoinen kuva USA:n tutkimusryhmän hajaantumisesta liiketoimintaan. Se panee lukijan kysymään Suomen kaltaisen maan tutkimusryhmien mahdollisuuksia "voittaa" toiminnan pitkäjänteisyydellä maailman dynaamisin kansantalous ja sen tutkimussaavutukset.

\section{TUTKIMUSTYÖ URA-}

\section{KEHITYKSEN TUKIJANA}

Yksi olennainen juonne on tutkijoiden urat. Tutkijoiden ja ryhmän on kyettävä joka tilanteessa löytämään toimintansa jatkomahdollisuus. Muuten ei synny sen paremmin väitöskirjoja kuin innovaatioita tai tuotteitakaan. Tutkimustoiminta on toi- sin sanoen voitava muotoilla yksilön näkökulmasta uraksi, jossa ei ole liian suuria katkoksia, alan vaihtoja tai mahdottomia tehtäviä. Mielestäni uranäkökulmaa on yleisesti laiminlyöty Suomessa. Sitä on usein tarkasteltu vain tutkijoiden toimeentulon kannalta, mutta se kaikesta päättäen on mitä olennaisin osaamisen kasvattamisen, tutkimusohjelmien ja tieteellisen tason kannalta. Tähän Eveliina Saaren väitöskirja tuo valaisua.

\section{TUTKIMUSRYHMÄN OPPIMINEN}

Eveliina Saari vetää tuloksensa yhteen löydöksinä. Tutkimusohjelman ja -ryhmän sisäiselle dynamiikalle käyttäjien verkosto todetaan olennaiseksi jännitteen luojaksi. Toinen löydös koskee tutkimusryhmän osoittamaa tulevaisuusorientaatiota ja potentiaalisen tulevaisuuden merkitystä tutkimusryhmän tämän päivän työn suuntaamisessa. (Tähän olisi saanut lisätukea Alfred Schutzin projektin käsitteestä). Verkostoja koskevat löydökset tiivistetään teesiin, jonka mukaan tutkimusryhmän ekspansiivinen oppiminen tapahtuu sekä tutkimusryhmien keskinäisessä verkostossa että verkostosuhteessa potentiaalisiin käyttäjiin. Kolmantena löydösryhmänä esitetään työnjakoa ja tutkijoiden uria koskevat tulokset.

Tutkielma jatkaa ansiokkaasti laboratorietnografista työtä käyttäen hyväksi konstruktivistisia ideoita, toimijaverkko -ajatuksia, Michael Lynchin mikrotasolla operoivaa etnometodologiaa ja Joan Fujimuran (doable problem) ajatuksia kokeiden, laboratorion ja sosiaalisen maailman välisistä suhteista.
KOULUKUNNAN EDUT JA RASITTEET

Tekijän omaksuma kulttuurihistoriallisen toiminnan teoria tarjoaa useitakin ajatuksellisia työvälineitä sekä perspektiivin oppimiseen. Sinänsä teoria on yleinen inhimillisen toiminnan käsitteistys, mutta tutkimusteoria siitä saadaan ottamalla mukaan tutkimusryhmän olosuhteita ja oppimisen teema. Tekijän taustayhteisö on ilmiselvästi tutkimuksellinen resurssi, mutta samalla taustayhteisössä luotu ajatusmalli ei välttämättä kommunikoi suoraan muiden vakiintuneiden käsitteistysten suuntaan ilman käännöksiä. Koulukuntamuodostuksesta on siis paitsi etunsa myös rajoitteita. Pääsääntöisesti työkalut kuitenkin toimivat, onhan toiminnan analyysi jo Aristoteleesta asti kehitelty pitkä traditio.

Yksi vaihtoehto pitkien aikajänteiden osalta ehkä olisi ollut tarkastelun kytkeminen kuhnilais-lakatosilaiseen tutkimusohjelman ajatukseen. Sovellutuksilla on tekijän itsensäkin erinomaisesti esiintuomia episteemisiä suhteita perustutkimuksen kohteeseen. Ulkoisena kritiikkinä voi lisäksi esittää, että erilaisten aikajänteiden teema olisi ansainnut vieläkin enemmän huomiota.

Kaiken kaikkiaan Eveliina Saari on esittänyt sellaista kuvausta tutkimustoiminnasta, jonka toivoisi olevan kaikkien tiedepolitiikan tekijöiden mielessä sekä organisaatioita ja verkostoja rakennettaessa että tutkimustoimintaa rahoitettaessa ja johdettaessa.

\section{Seppo Raiski}

